DOI https://doi.org/10.33766/2524-0323.86.42-52

УДК 342.922:351.746

А. Г. Мосейко,

старший викладач

кафедри загально-правових дисциплін

Дніпровського гуманітарного університету

(м. Дніпро, Україна)

e-mail:mpv12@i.ua

iD https:// orcid.org/0000-0003-0749-5491

\title{
НАЦІОНАЛЬНА БЕЗПЕКА УКРАЇНИ ЯК ОБ'ЄКТ ПУБЛІЧНОГО АДМІНІСТРУВАННЯ
}

\begin{abstract}
Статтю присвячено дослідженню особливостей публічного адміністрування в сфері національної безпеки України. Розкрито сутність держави, основним призначенням якої необхідно вважати досягнення загальної безпеки й благополуччя. Визначено сучасну роль держави в умовах глобалізації, що суттєво змінюе іiі традиційні функції та методи здійснення управлінської діяльності. Наголошено на доцільності виокремлення напрямів публічного адміністрування в сфері національної безпеки України, де кожний напрям передбачає потенційно можливі методи впливу, об'єкт публічного адміністрування та сукупність відповідних заходів протидії на рівні держави. Охарактеризовано значення суспільних відносин, пов'язаних із забезпеченням національної безпеки в окремі групи, об'єкти, що дало б змогу проаналізувати їх, коригувати та контролювати 3 боку суспільства. Систему напрямів публічного адміністрування в сфері національної безпеки України розглянуто з огляду на зростання їх актуальності та сформульовано наступним чином: військово-силовий, екологічний, економічний, політичний та інформаційний. Акцентовано увагу на новому розумінні взаємовпливу та взаємозалежності національного й міжнародного аспектів безпеки, де національна безпека окремої держави є частиною або підсистемою регіональної безпеки, і врешті, безпеки міжнародної та глобальної.

Ключові слова: глобальна безпека, державна безпека, міжнародна безпека, національна безпека, публічне адміністрування, об'єкт публічного адміністрування, регіональна безпека, суспільна безпека
\end{abstract}

Постановка проблеми. Важливою проблемою державотворення, яка супроводжує людство на всіх історичних етапах розвитку суспільно-правових відносин, є забезпечення національної безпеки держави як важливої та обов'язкової передумови й мети іï сталого ефективного розвитку. Проте й на сьогодні це питання не лише залишається належно не вирішеним, а й набуває все більшого резонансу, оскільки сфера національної безпеки є стратегічно значимою для України, особливо під час здійснення численних реформ в умовах стрімкого якісного та кількісного зростання різноманітних внутрішніх і зовнішніх ризиків, загроз і викликів. 3 огляду на це в Стратегії національної безпеки України, затвердженій Указом Президента України в травні 2015 р., зазначено, що докорінні зміни в зовнішньому та внутрішньому середовищі безпеки України обумовлюють потребу створення якісно нової системи національної безпеки нашої країни, а також внесення відповідних змін до 
Воєнної доктрини держави. За таких умов актуальним є дослідження передусім адміністративно-правових аспектів національної безпеки України та ï безпосереднього усвідомлення як особливого об'єкта публічного адміністрування, зважаючи на специфіку владних повноважень суб'єктів у сфері національної безпеки i, відповідно, ефективність їх здійснення.

Аналіз останніх досліджень і публікацій. Проблеми публічного адміністрування в галузі національної безпеки держави та окремі їі складові ставали об'єктом дослідження як іноземних, так і вітчизняних учених, зокрема Ю. П. Битяка, К. О. Ващенка, О. М. Гончаренка, В. П. Ємельянова, А. Б. Качинського, Ю.В.Ковбасюка, В.К.Колпакова, В. А. Ліпкана, В.В. Мадіссона, Г. В. Новицького, В. М. Олуйка, В. М. Пасічника, В. Г. Пилипчука, А. І. Семенченка, Г. П. Ситника, 3. Д. Чуйка, О. А. Чувакова, В. А. Шахова, О. В. Шамара та інших. Але з огляду на постійні зміни як внутрішнього, так і зовнішнього політико-правового середовища, а також й інших суспільно значущих сфер у країні, проблематика національної безпеки держави i, зокрема національної безпеки держави як об'єкта публічного адміністрування, потребує подальшого розвитку та дослідження.

Формування цілей. Метою статті є спроба комплексного дослідження національної безпеки України як об'єкта публічного адміністрування.

Виклад основного матеріалу. Відповідно до ст. 17 Основного Закону України захист суверенітету й територіальної цілісності України, забезпечення ії економічної та інформаційної безпеки є найважливішими функціями держави, справою всього українського народу [1], тому актуальним для України є проведення динамічних, обгрунтованих та комплексних реформ, які мають забезпечити модернізацію держави в контексті залучення кращого світового досвіду, що, своєю чергою, передбачає ефективне впровадження досягнень теорії та практики державного управління в сфері забезпечення національної безпеки, особливо в контексті тих викликів, з якими стикнулася Україна в 2014 році [2].

Проте реалізація ефективного впровадження досягнень теорії та практики державного управління в сфері забезпечення національної безпеки ускладнюється тим фактом, що наукове знання в цій галузі неналежно систематизовано, а і низка проблем у системі забезпечення національної безпеки України значно зумовлена інтелектуальною неспроможністю державно-управлінської науки та управлінських кадрів дати адекватні відповіді на виклики сьогодення, із чим варто погодитися. На актуальності цієї проблематики наголошують також експерти Центру О. Разумкова, стверджуючи, що загальна ситуація безпеки останнім часом дійсно змінилася. І це не лише поява нових загроз, але й відновлення старих. До того ж науковці звертають увагу загалом на зміну геополітичної ситуації навколо України, яка фактично є буферною (сірою) зоною між наявними потужними воєнно-політичними й воєнно-економічними системами світу. Зокрема С. Крук справедливо зазначає, що суспільні науки, передусім юридична, мають надати відповідь на питання, яким чином зупинити державо-руйнівні процеси, які відбуваються в державі. Це є питанням національної безпеки [3]. Ми цілком погоджуємося з поглядом I. Тацишина, 
який акцентує увагу на тому, що розробка ефективної державної політики національної безпеки ускладнюється тим, що вітчизняні та іноземні дослідники, державні діячі, а також нормативні документи дають різні тлумачення сутності поняття «національна безпека», вкладаючи в це поняття різний зміст [4, с. 46-47].

Поняття «національної безпеки» має велику кількість вимірів та аспектів, різниця між якими полягає зокрема й у відповідних позиціях, з яких розглядається це питання, оскільки навіть за наявності принципових узгоджень щодо методології та системи світогляду помітні розбіжності в баченні сутності та змісту національної безпеки в юристів, на відміну від військових, економістів, політологів тощо. 3 огляду на це, науковці відносять аналізоване поняття до інтегративних, міждисциплінарних, багатоаспектних. Особливим змістом поняття «національна безпека» наповнюється через появу в Україні тимчасово окупованих територій i запровадження на них спеціального правового режиму [5].

Вважають, що вперше дефініцію «національна безпека» застосували в США (причому не як правову, а як зовнішньополітичну категорію) у 1904 р. під час оголошення тодішнім президентом США послання до Конгресу, у якому в інтересах національної безпеки обгрунтовувалося приєднання зони Панамського каналу. До слова, американська концепція національної безпеки передбачала розгляд останньої як частини національних інтересів. У зв'язку з цим С. Крук виділяє два підходи до розуміння національної безпеки: національна безпека в контексті національних інтересів; національна безпека в контексті базисних цінностей суспільства [6, с. 36]. Згідно з першим підходом зміст національної безпеки вбачають у ступені захищеності національних інтересів; стані захищеності життєво важливих інтересів особи, суспільства й держави, довкілля в різних сферах життєдіяльності від внутрішніх і зовнішніх загроз; стані захищеності національних інтересів від різного роду загроз, що досягається завдяки цілеспрямованій діяльності органів державної влади та інститутів громадянського суспільства для гарантування прав людини й основоположних свобод, їх прогресивного розвитку та стабільності конституційного ладу.

Прихильники другого підходу, зокрема Д. Беззубов, наголошують, що зміст національної безпеки полягає в захищеності не національних інтересів, а власне держави від внутрішніх і зовнішніх загроз, у стійкості до несприятливих впливів ззовні, у забезпеченні такого існування держави, яке гарантує нормальні умови для розвитку суспільства, а також життєдіяльності його громадян [7, с. 47-48], тобто національна безпека держави полягає в захисті не національних інтересів, а належних i необхідних умов існування і держави, і суспільства, й окремих громадян. Відповідно, забезпечення таких сприятливих умов $\epsilon$ необхідною передумовою реалізації власне національних інтересів і цілей.

Справедливим у цьому контексті вважаємо зауваження С. Шеньо, який вважає, що при визначенні поняття національної безпеки України потрібно 
закцентувати на утвердженні й забезпеченні становища українського народу як самостійного суб'єкта політичної влади та рівноправного учасника міжнародних відносин, носія суверенітету й основного джерела влади у своїй країні, коли досягається стан захищеності життєво важливих інтересів людини і громадянина, суспільства та держави, де відсутні загрози національним інтересам, національним цінностям та національному способу життя, при якому забезпечується його стійке існування, саморозвиток і прогрес, задоволення і реалізація життєвих потреб, здатність до ефективної нейтралізації внутрішніх і зовнішніх загроз [8, с. 22-24].

Досліджуючи сутність поняття національної безпеки держави, доцільно звернути увагу на законодавчо закріплене визначення цієї категорії. Відповідно до ст. 1 закону України «Про національну безпеку України» національна безпека - це захищеність життєво важливих інтересів людини і громадянина, суспільства, захищеність державного суверенітету, територіальної цілісності, демократичного конституційного ладу та інших національних інтересів України від реальних та потенційних загроз [9]. До того ж законодавець під національними інтересами розуміє життєво важливі матеріальні, інтелектуальні й духовні цінності українського народу як носія суверенітету та єдиного джерела влади в Україні, визначальні потреби суспільства й держави, реалізація яких гарантує державний суверенітет

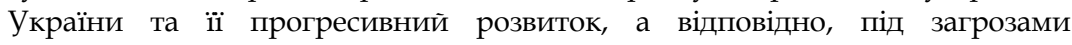
національній безпеці - наявні та потенційно можливі явища й чинники, що створюють небезпеку життєво важливим національним інтересам. Зауважимо, що державна політика в сферах національної безпеки й оборони спрямована на захист: людини й громадянина - їхніх життя й гідності, конституційних прав і свобод, безпечних умов життедіяльності; суспільства - його демократичних цінностей, добробуту та умов для сталого розвитку; держави - ії конституційного ладу, суверенітету, територіальної цілісності та недоторканності; території, навколишнього природного середовища - від надзвичайних ситуацій. До того ж має бути дотриманий баланс між інтересами держави та людини [10].

Водночас, досліджуючи сутність та особливості національної безпеки держави як об'єкта адміністративно-правової охорони та захисту, цілком погоджуємося з В. Кривцовою та І. Усатюк, які стверджують, що важливе місце у визначенні багатовимірного змісту досліджуваного поняття має адміністративно-правовий аспект, оскільки особливістю національної безпеки з адміністративно-правових позицій є те, що однією зі сторін адміністративно-правових відносин виступає відповідний носій владних повноважень у сфері національної безпеки щодо інших суб'єктів цих відносин [11, с. 65]. Ними виступають суб'єкти управління національною безпекою держави. Адміністративне право (у найбільш загальному вигляді) як сукупність правових норм, що регулюють суспільні відносини у сфері державного управління, виступає спеціальним юридичним заходом здійснення свідомого цілеспрямованого впливу суб'єкта управління на загрози та небезпеки, через який створюються необхідні й достатні умови для прогресивного розвитку українських національних інтересів, джерел 
добробуту українського народу, а також забезпечується ефективне функціонування системи національної безпеки. Також зазначимо, що напрями адміністративно-правового регулювання сфери національної безпеки залежать від конкретних національних інтересів (у сферах економіки, фінансів, екології, науково-технічного розвитку, культури, соціальній сфері тощо) і можуть бути обумовлені як власним існуванням, так і необхідністю їх охорони з боку адміністративного права.

Крім того, досліджуючи особливості національної безпеки як об'єкта адміністративно-правової охорони та захисту, зауважимо, що суд задовольняє вимоги позивача в інтересах національної безпеки та громадського порядку в разі, якщо визнає, що проведення зборів, мітингів, походів, демонстрацій чи інших зібрань може створити реальну небезпеку заворушень чи вчинення кримінальних правопорушень, загрозу здоров'ю населення або правам і свободам інших людей, як зазначається в ст. 182 Кодексу адміністративного судочинства [12].

Отже, під національною безпекою держави як об'єкта публічного адміністрування пропонуємо розуміти систему суспільно-правових відносин, які виникають, розвиваються чи припиняються у зв'язку 3 необхідністю досягнення й забезпечення стану захищеності держави, суспільства, людини та громадянина, а саме: їхніх інтересів та цінностей; гарантованих їм прав і свобод, зокрема державного суверенітету, конституційного ладу, територіальної цілісності, економічного, науковотехнічного, оборонного потенціалу держави тощо від внутрішніх i зовнішніх загроз і небезпек, попередження та нейтралізації їх негативного впливу для реалізації національних інтересів, цілей і досягнення сталого розвитку суспільства, і які, відповідно, потребують адміністративно-правової охорони та захисту, регулюючись нормами адміністративного права.

Зазначимо, що відповідно до положень Конституції України забезпечення державної безпеки покладається на відповідні військові формування та правоохоронні органи держави, організація й порядок діяльності яких визначаються законом. Зовнішньополітична діяльність України спрямована на забезпечення їі національних інтересів і безпеки через підтримання мирного й взаємовигідного співробітництва з членами міжнародного співтовариства за загальновизнаними принципами і нормами міжнародного права (ст. 18). Також Конституцією встановлено, що основи національної безпеки визначаються тільки законами України (ст. 92). Відповідно до вказаної статті закон України «Про національну безпеку України» визначає основні принципи, що визначають порядок формування державної політики в сферах національної безпеки й оборони, а саме: верховенство права, підзвітність, законність, прозорість та дотримання засад демократичного цивільного контролю за функціонуванням сектору безпеки й оборони та застосуванням сили; дотримання норм міжнародного права, участь в інтересах України в міжнародних зусиллях з підтримання миру й безпеки, міждержавних системах та механізмах міжнародної колективної безпеки; розвиток сектору безпеки й оборони як основного інструменту 
реалізації державної політики в сферах національної безпеки й оборони [8]. Відповідно до цього закону розробляються й затверджуються Президентом України Стратегія національної безпеки України та Воєнна доктрина України, доктрини, концепції, стратегії і програми, якими визначаються цільові настанови та керівні принципи воєнного будівництва, а також напрями діяльності органів державної влади в конкретній обстановці для своєчасного виявлення, відвернення і нейтралізації реальних і потенційних загроз національним інтересам України.

Фундаментальними національними інтересами України є наступні: державний суверенітет i територіальна цілісність, демократичний конституційний лад, недопущення втручання у внутрішні справи України; сталий розвиток національної економіки, громадянського суспільства й держави для забезпечення зростання рівня та якості життя населення; інтеграція України в європейський політичний, економічний, безпековий, правовий простір, набуття членства в Європейському Союзі та в Організації Північноатлантичного договору, розвиток рівноправних взаємовигідних відносин 3 іншими державами. Тобто 3 урахуванням геополітичної i внутрішньої обстановки в Україні діяльність усіх державних органів має бути зосереджена на прогнозуванні, своєчасному виявленні, попередженні та нейтралізації зовнішніх і внутрішніх загроз національній безпеці, захисті суверенітету й територіальної цілісності України, безпеки тї прикордонного простору, піднесенні економіки країни, забезпеченні особистої безпеки, конституційних прав і свобод людини й громадянина, викоріненні злочинності, удосконаленні системи державної влади, зміцненні законності и правопорядку та збереженні соціально-політичної стабільності суспільства, зміцненні позицій України у світі, підтриманні на належному рівні ऑï оборонного потенціалу й обороноздатності, радикальному поліпшенні екологічної ситуації.

Для реалізації вказаних вище національних інтересів була затверджена Стратегія національної безпеки України, орієнтована на такі цілі: мінімізацію загроз державному суверенітету та створення умов для відновлення територіальної цілісності України в межах міжнародновизнаного державного кордону України, гарантування мирного майбутнього України як суверенної і незалежної, демократичної, соціальної, правової держави; утвердження прав і свобод людини й громадянина, забезпечення нової якості економічного, соціального й гуманітарного розвитку, забезпечення інтеграції України до Європейського Союзу та формування умов для вступу в НАТО.

До того ж у Стратегії наведено перелік актуальних загроз національній безпеці України, серед яких виділимо наступні: військову агресію; розвідувально-підривну й диверсійну діяльність, дії, спрямовані на розпалювання міжетнічної, міжконфесійної, соціальної ворожнечі й ненависті, сепаратизму й тероризму; нарощування військових угруповань; блокування зусиль України щодо протидії монополізації стратегічних галузей національної економіки, щодо позбавлення залежності від монопольних постачань критичної сировини насамперед енергетичних 
ресурсів; торговельно-економічну війну; інформаційно-психологічну війну, приниження української мови й культури, фальшування української історії, формування російськими засобами масової комунікації альтернативної до дійсності, викривленої інформаційної картини світу; неефективність системи забезпечення національної безпеки й оборони України; корупцію та неефективну систему державного управління; економічну кризу, виснаження фінансових ресурсів держави, зниження рівня життя населення; загрози енергетичній, інформаційній безпеці, кібербезпеці, безпеці інформаційних ресурсів, безпеці критичної інфраструктури тощо [13]. Проте, на наш погляд, деякі з наведених загроз більшою мірою відповідають за суттю факторам впливу на якість забезпечення національної безпеки України.

Як слушно зазначає В. Антонов, особливими рисами національної безпеки є таке: незалежність - здатність держави здійснювати незалежну внутрішню й зовнішню політику відповідно до своїх національних інтересів, самостійно вирішувати питання свого державного устрою, розпоряджатися власними національними ресурсами, усувати залежності, що є загрозою державному суверенітету, установлювати й розвивати рівноправні відносини 3 іншими країнами; стійкість і стабільність - забезпечення міцності, надійності та збалансованого функціонування усіх підсистем суспільства, створення системи національної безпеки, яка здатна витримувати, стримувати й нейтралізувати впливи дестабілізуючих внутрішніх та зовнішніх чинників, вчасно реагувати на них, а також здатність підтримувати баланс інтересів між державами на міжнародній арені, захищати власні інтереси в разі необхідності; здатність до саморозвитку прогресу - усунення перешкод динамічному розвитку держави, суспільства й особи, створення сприятливого клімату для здійснення постійної модернізації, удосконалення та розвитку потенціалу країни [14, с. 283- 284]. При цьому слід погодитися, що забезпечення національної безпеки досягається інтеграцією питань внутрішньої та зовнішньої політики, створенням державної та недержавної системи забезпечення національної безпеки, ужиттям у своїй державній політиці різних засобів для збереження суверенітету, фізичної цілісності й території, підтримкою паритетних відносин з іншими країнами світу тощо й передбачає досягнення балансу інтересів суспільства, держави та тї громадян.

Висновки. Отже, доцільно виділити такі основні особливості національної безпеки України як об'єкта публічного адміністрування: вона $є$ системним, багатоаспектним явищем; національна безпека має завжди розглядатися в контексті базових цінностей суспільства, а не лише національних інтересів; цей об'єкт публічного адміністрування є однією 3 найважливіших цілей держави та передумовою досягнення цілей і реалізації інтересів держави та суспільства; національна безпека не є тотожною та не протиставляється державній або суспільній безпеці, оскільки об'єктами національної безпеки є людина та громадянин, суспільство та держава, перебуваючи в тісних взаємозв'язках і залежностях одне 3 одним; 
обов'язковий ії суб'єкт є носієм владних повноважень у сфері національної безпеки (суб'єктом публічного адміністрування національною безпекою держави) щодо інших суб'єктів цих відносин; вона є складовою міжнародної, регіональної та глобальної безпеки; національна безпека регулюється зокрема й нормами адміністративного права.

\section{Використані джерела:}

1. Конституція України: прийнята на п'ятій сесії Верховної Ради України 28 червня 1996 року. Відомості Верховної Ради України. 1996. № 30. Ст. 141.

2. Нестерович В. Ф. Громадські протести на окремих територіях Українського Донбасу протягом весни 2014 року: причини та наслідки. Віче. 2014. № 21. С. 14-17.

3. Крук С. І. Планування у сфері національної безпеки України. Теорія та практика державного управління $і$ місиевого самоврядування. 2019. № 1. URL.: http://nbuv.gov.ua/UJRN/Ttpdu_2019_1_24 (дата звернення: 01.08.2019).

4. Тацишин І. Національна безпека України та ії складові елементи. Правова інформатика. 2008. № 4. С. 46-49.

5. Нестерович В. Ф. Верховенство права та забезпечення прав людини на тимчасово окупованих територіях України. Наукові записки НаУКМА. 2017. Т. 200. Юридичні науки. С. 85-92.

6. Крук С. І. Інституціоналізація національної безпеки в системі державного управління. Вчені записки Таврійського начіонального університету імені В. I. Вернадського. Серія : Державне управління. 2018. Т. 29(68), № 5. С. 34-37.

7. Беззубов Д. О. Проблеми теорії публічного адміністрування в сфері забезпечення національної безпеки. Наукові записки [Центральноукраїнського державного педагогічного університету імені Володимира Винниченка]. Серія : Право. 2018. Вип. 5. С. 45-49.

8. Шеньо С. Європейський та євроатлантичний вимір національної безпеки України. Геополітика України: історія і сучасність. 2014. Вип. 1. С.21-35.

9. Про національну безпеку України : закон України від 21 червня 2018 р. № 2469-VIII. Верховна Рада України. URL: http:/ / zakon.rada.gov.ua/go/2469-19 (дата звернення: 01.08.2019).

10. Нестерович В. Ф. Категорія «інтерес» у правотворчості: загальнотеоретичні аспекти. Вісник Луганського державного університету внутрішніх справ. 2006. № 1. C. 73-78.

11. Кривцова В., Усатюк І. Переваги та зауваги щодо прийнятого 21 червня 2018 року закону «Про національну безпеку України». Актуальні проблеми державного управління. 2018. Вип. 4. С. 64-69.

12. Кодекс адміністративного судочинства України : закон Украӥни від 06 липня 2005 p. № 2747-IV. Верховна Рада України. URL : http://www.zakon.rada.gov.ua/ go/2747-15 ( дата звернення: 01.08.2019).

13. Про рішення Ради національної безпеки й оборони України від 06 травня 2015 року «Про Стратегію національної безпеки України» : Указ Президента України від 26 травня 2015 р. № 287/2015. Верховна Рада України. URL : http:/ /zakon.rada.gov.ua/laws/show/287/2015 (дата звернення: 01.08.2019).

14. Конституційно-правові засади національної безпеки України : монографія / В. О. Антонов; наук. ред. Ю. С. Шемшученко. Київ: ТАЛКОМ, 2017. 576 с. 


\section{Reference}

1. Konstytutsiya Ukrayiny: pryynyata na p"yatiy sesiyi Verkhovnoyi Rady Ukrayiny 28 chervnya 1996 roku [Constitution of Ukraine: adopted at the fifth session of the Verkhovna Rada of Ukraine on June 28, 1996]. Vidomosti Verkhovnoyi Rady Ukrayiny. 1996. № 30. St. 141. [in Ukrainian]

2. Nesterovych V.F. Hromads'ki protesty na okremykh terytoriyakh Ukrayins'koho Donbasu protyahom vesny 2014 roku: prychyny ta naslidky [Public protests in certain areas of the Ukrainian Donbass during the spring of 2014: causes and consequences]. Viche. 2014. vol. 21. s. 14-17.

3. Kruk S. I. Planuvannya u sferi natsional'noyi bezpeky Ukrayiny. Teoriya ta praktyka derzhavnoho upravlinnya i mistsevoho samovryaduvannya [Planning in the sphere of national security of Ukraine]. Theory and Practice of Public Administration and Local SelfGovernment. 2019. vol. 1. URL.: http://nbuv.gov.ua/UJRN/Ttpdu_2019_1_24

4. Tatsyshyn I. Natsional'na bezpeka Ukrayiny ta yiyi skladovi element [National Security of Ukraine and its constituent elements]. Pravova informatyka. 2008. vol. 4. p. 46-49.

5. Nesterovych V.F. Verkhovenstvo prava ta zabezpechennya prav lyudyny na tymchasovo okupovanykh terytoriyakh Ukrayiny [The rule of law and human rights in the temporarily occupied territories of Ukraine]. Naukovi zapysky NaUKMA. 2017. vol. 200. Yurydychni nauky. s. 85-92. [in Ukrainian]

6. Kruk S. I. Instytutsionalizatsiya natsional'noyi bezpeky v systemi derzhavnoho upravlinnya [Institutionalization of National Security in the System of Public Administration]. Vcheni zapysky Tavriys'koho natsional'noho universytetu imeni V. I. Vernads'koho. Seriya: Derzhavne upravlinnya. 2018. T. 29(68), vol. 5. s. 34-37.

7. Bezzubov D. O. Problemy teoriyi publichnoho administruvannya v sferi zabezpechennya natsional'noyi bezpeky [Problems of the theory of public administration in the field of national security]. Naukovi zapysky [Tsentral'noukrayins'koho derzhavnoho pedahohichnoho universytetu imeni Volodymyra Vynnychenka]. Seriya: Pravo. 2018. vol. 5. s. 45-49.

8. Shen'o S. Yevropeys'kyy ta yevroatlantychnyy vymir natsional'noyi bezpeky Ukrayiny [The European and Euro-Atlantic dimension of Ukraine's national security]. Heopolityka Ukrayiny: istoriya i suchasnist'. 2014. vol. 1. p. 21-35.

9. Pro natsional'nu bezpeku Ukrayiny : Zakon Ukrayiny vid 21 chervnya $2018 \mathrm{r}$. № 2469-VIII [On National Security of Ukraine: Law of Ukraine dated June 21, 2018, No. 2469-VIII]. Verkhovna Rada of Ukraine. URL: http:/ / zakon.rada.gov.ua/go/2469-19.

10. Nesterovych V.F. Katehoriya «interes» u pravotvorchosti: zahal'noteoretychni aspekty [Category "interest" in law-making: general theoretical aspects]. Visnyk Luhans'koho derzhavnoho universytetu vnutrishnikh sprav. 2006. vol. 1. s. 73-78.

11. Kryvtsova V., Usatyuk I. Perevahy ta zauvahy shchodo pryynyatoho 21 chervnya 2018 roku Zakonu «Pro natsional'nu bezpeku Ukrayiny» [Advantages and Observations on the Law "On National Security of Ukraine" adopted on June 21, 2018]. Aktual'ni problemy derzhavnoho upravlinnya. 2018. vol. 4. s. 64-69.

12. Kodeks administratyvnoho sudochynstva Ukrayiny: Zakon Ukrayiny vid 6 lypnya 2005 r. № 2747-IV. Verkhovna Rada of Ukraine. Verkhovna Rada of Ukraine. URL: http:/ / www.zakon.rada.gov.ua/go/2747-15.

13. Pro rishennya Rady natsional'noyi bezpeky i oborony Ukrayiny vid 6 travnya 2015 roku «Pro Stratehiyu natsional'noyi bezpeky Ukrayiny»: Ukaz Prezydenta 
Ukrayiny vid 26 travnya 2015 r. № 287/2015 [On the decision of the National Security and Defense Council of Ukraine dated May 6, 2015 "On the Strategy of National Security of Ukraine": Decree of the President of Ukraine dated May 26, 2015, No. 287/2015]. URL.: http:/ / zakon.rada.gov.ua/laws/show/287/ 2015.

14. Konstytutsiyno-pravovi zasady natsional'noyi bezpeky Ukrayiny: monohrafiya [Constitutional and Legal Principles of National Security of Ukraine: monograph] / V. O. Antonov; nauk. red. YU.S. Shemshuchenko. Kyyiv: TALKOM, 2017. 576 p.

Стаття надіӥшла до редколегї 12.04.2019

Мосейко А. Г., старший преподаватель кафедры общеправовых дисциплин Днепровского гуманитарного университета (г. Днепр, Украина)

\section{НАЦИОНАЛЬНАЯ БЕЗОПАСНОСТЬ УКРАИНЫ КАК ОБЪЕКТ ПУБЛИЧНОГО АДМИНИСТРИРОВАНИЯ}

Статья посвящена исследованию особенностей публичного администрирования в сфере национальной безопасности Украины. Раскрыта сущность государства, основным предназначением которого следует считать достижение общей безопасности и благополучия. Определена роль современного государства в условиях глобализации, которая существенно изменяет его традиционные функции и методы осуществления управленческой деятельности. Сделан акцент на целесообразности выделения направлений публичного администрирования в сфере национальной безопасности Украины, где каждое направление предусматривает возможные методы влияния, объект публичного администрирования и совокупность соответствующих мероприятий по противодействию на государственном уровне. Охарактеризовано значение общественных отношений, связанных с обеспечением национальной безопасности в отдельные группы, объекты, что позволило бы анализировать их и осуществлять государственный контроль со стороны общества. Система направлений публичного администрирования в сфере национальной безопасности Украины рассмотрена с учётом степени их актуальности и сформулирована следующим образом: военно-силовое, экологическое, экономическое, политическое и информационное. Акцентировано внимание на новом понимании взаимовлияния и взаимозависимости национального и международного аспектов безопасности, где национальная безопасность отдельного государства является частью или подсистемой региональной безопасности, которая, в свою очередь безопасности международной и глобальной.

Ключевые слова: глобальная безопасность, государственная безопасность, международная безопасность, национальная безопасность, публичное администрирование, объект публичного администрирования, региональная безопасность, общественная безопасность. 
Moseyko A., Senior Lecturer of the Department of General Legal disciplines, Dnipro Humanitarian University (Dnipro, Ukraine)

\title{
NATIONAL SECURITY OF UKRAINE AS AN OBJECT OF PUBLIC ADMINISTRATION
}

The article is devoted to the study of the features of public administration in the field of national security of Ukraine. The essence of the state is revealed, the main purpose of which should be considered the achievement of general security and wellbeing. The role of the modern state in the context of globalization, which significantly changes its traditional functions and methods of management, is defined. Emphasis is placed on the feasibility of identifying areas of public administration in the field of national security of Ukraine, where each direction provides for possible methods of influence, the object of public administration and a set of relevant measures to counter at the state level. The significance of social relations associated with ensuring national security into separate groups, objects, which would allow analyzing them and exercising state control on the part of society, is characterized. The system of areas of public administration in the field of national security of Ukraine is considered taking into account the degree of their relevance and is formulated as follows: military, environmental, economic, political and informational direction. Attention is focused on the new understanding of the mutual influence and interdependence of the national and international aspects of security, where the national security of an individual state is part of or subsystem of regional security, which, in turn, is international and global security.

Key words: global security, state security, international security, national security, public administration, public administration facility, regional security, public security.

\section{DOI}

УДК 342.572

\author{
В. Ф. Нестерович, \\ доктор юридичних наук, доцент \\ завідувач кафедри державно-правових дисциплін \\ Луганського державного університету \\ внутрішніх справ імені Е. О. Дідоренка \\ (м. Сєвєродонецьк, Україна) \\ e-mail: mail@lduvs.edu.ua \\ (iD https://orcid.org/0000-0003-2614-0426
}

\section{ОСОБЛИВОСТІ ПРОВЕДЕННЯ ВИБОРІВ ДО ОРГАНІВ МІСЦЕВОГО САМОВРЯДУВАННЯ В УКРАЇНІ}

У статті розкрито особливості проведення виборів до органів місцевого самоврядування в Україні. Указано, що вибори до органів місцевого самоврядування є найбільш наближеним до громадян видом виборів. Чергові вибори до органів місцевого самоврядування є чи не найбільш складними. При 